\title{
Hvorfor viser mine mails en 'forkert' afsender, når jeg anvender OJS's interne mailsystem i min kommunikation med forfatter og bedømmer - og hvordan løser jeg det problem?
}

\section{Niels Erik Frederiksen}

I tidligere udgaver af OJS indsatte programmet altid den pågældende redaktørs e-mailadresse, når den interne mail blev aktiveret. Den redaktør eller sektionsredaktør, der var knyttet til redigeringen af artiklen kom - i kommunikationen med forfatter og bedømmer - derfor også til at stå som afsender, når vedkommende sendte de interne mails videre. Dette har imidlertid i enkelte tilfælde vist sig at medføre fejlsendinger, hvor mails er blevet tolket som spam eller endnu mere drastisk, helt kasseret af modtagerens server. Derfor har OJS's udviklingsteam valgt - ligesom mange andre udbydere, som f.eks. Wordpress - at benytte én central mailadresse. Hos OJS har man valgt at anvende den e-mailadresse, som det enkelte tidsskrift har indsat i forbindelse med 'Primær kontaktperson'. Den primære kontaktperson indsættes af tidsskriftschefen under 'Konfiguration' > 'Detaljer' > '1.2 Primærkontaktperson'.

På dette sted kunne den enkelte tidsskriftsredaktion overveje at anskaffe og indsætte en tidsskriftsrelateret mailadresse og i navnefeltet eventuelt indsætte tidsskriftsnavnet:

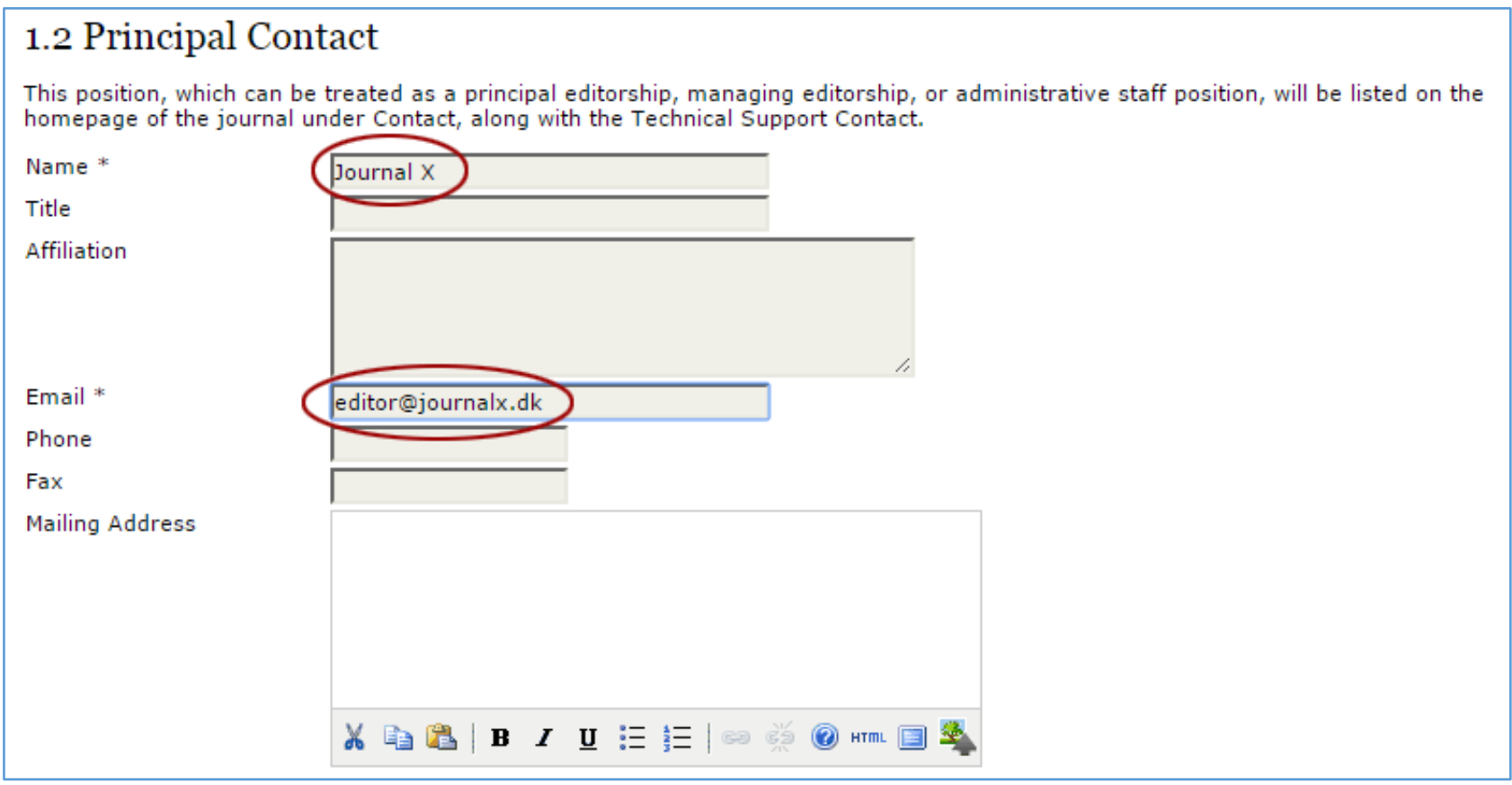


Fra version 2.4.6.0 er der under 'Konfiguration' > 'Detaljer' >'1.4 Email Identification' indsat et ekstra felt ('Email Header'), hvor man kan indsætte en uddybende tekst. Det kunne være som her:

\subsection{Email Identification}

The prepared emails that are sent by the system on behalf of the journal will begin with the following header. These emails will be addressed from the Principal Contact, so it's important to clarify that the Primary Contact is not necessarily responsible for the message content, which may be sent on behalf of a different user.

\begin{tabular}{|c|c|}
\hline & $\begin{array}{l}\text { You are receiving this email on behalf of JournalX. In the event of a } \\
\text { requested response, you may respond directly to this email. }\end{array}$ \\
\hline \multicolumn{2}{|c|}{$\begin{array}{l}\text { The prepared emails that are sent by the system on behalf of the journal will have the following signature added to the end. The body of } \\
\text { the prepared emails are available for editing under Journal Management. }\end{array}$} \\
\hline Signature & $\overline{\overline{\text { JournalX }}}$ \\
\hline \multicolumn{2}{|c|}{ Any undeliverable emails will result in an error message to this address. } \\
\hline Bounce Address & $\begin{array}{l}\text { Note: To activate this option, the site administrator must enable the allow_envelope_sender option in the OJS } \\
\text { configuration file. Additional server configuration may be required to support this functionality (which may not } \\
\text { be possible on all servers), as indicated in the OJS documentation. }\end{array}$ \\
\hline
\end{tabular}

Forslag til hvordan 'Email Header' kan udfyldes

En sådan opsætning vil resultere i, at modtageren af de interne mails, det være sig forfatter såvel som bedømmer, får en mail, der vil se ud som nedenfor:

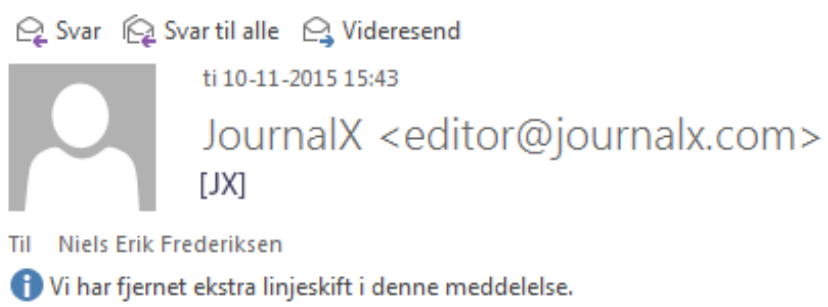

(i) Vi har fjernet ekstra linjeskift i denne meddelelse.

You are receiving this email on behalf of JournalX. In the event of a requested response, you may respond directly to this email.

Sådan vil mailen se ud

Vælger modtageren at svare direkte via $\bigoplus_{\text {Svar }}$ vil svar-mailen blive sendt til afsenderen af mailen og ikke til den mailadresse, der figurerer i afsenderfeltet, her editor@journalx.com 